\title{
Identification of some human pathogenic fungi using four DNA extraction methods
}

\author{
*15AMUEL, TO; ${ }^{2}$ EBABHI, AM; ${ }^{1}$ ADEKUNLE, AA \\ 'Department of Botany, Faculty of Science, University of Lagos, Akoka-Yaba, Lagos, Nigeria \\ ${ }^{2}$ Biology Unit, Department of Education Science, Distance Learning Institute, University of Lagos, Akoka, Lagos, Nigeria \\ temmitade@yahoo.com,ebahbi.meg@gmail.com, aaded63@yahoo.com \\ *Corresponding author: E-mail: temmitade@yahoo.com; tosamuel@yahoo.com \\ Tel: 2348036410449
}

\begin{abstract}
Dermatophytes being animal and human pathogenic fungi infect some human at one point or the other in their lifetime. For effective control of dermatophytes, accurate identification of the specific species/strain involved must be known. Stocks from pathogenic fungi isolated from infected areas on different patients, around Lagos-Nigeria were analysed using molecular methods (DNA extraction, PCR-RFLP and DNA sequencing). Four DNA extraction protocols were employed in the identification of the fungal isolates. Sixteen different fungal isolates were identified, and based on the molecular data these were classified into six species of dermatophytes belonging to the genera Microsporum, Trichophyton and Epidermaphyton, two species of systemic mycoses fungi and eight opportunistic human pathogenic fungi. The results also revealed that CTAB protocol, Modified CTAB protocol and the GNOME kit used in this work were only able to extract non-dermatophytes DNA. Only the Zymo DNA kit was able to isolate dermatophytes DNA. DNA extraction which is the first step in all molecular studies showed that one DNA extraction method might not be able to extract all fungal DNA for proper identification, diagnosis and treatment of fungal infections. (C) JASEM

https://dx.doi.org/10.4314/jasem.v21i6.14
\end{abstract}

Keywords: Dermatophytes, DNA extraction, Identification, Protocols.

Dermatomycoses is contagious and represents a significant health problem in Nigeria. In particular, Lagos metropolis has a higher incidence of dermatomycoses due to crowded living conditions (Adetosoye, 1977; Ogbonna et al., 1985; Anosike et al., 2005). Incidences of the prevalence is not only particular to Lagos-Nigeria but is observed in many countries and crowded places in the world. For instance, Lakshmanan et al. (2015) reported a high incidence of fungal infection in rural India while Teklebirhan and Bitew (2015) reported a prevalence of $79.4 \%$ in 242 sampled cases.

The current diagnosis of dermatomycoses in most mycological laboratories inclusive of Lagos state, Nigeria is based upon conventional methods which is not species-specific. This does not give the accurate diagnostic results as the etiological patterns of most pathogenic organisms are changing just as there is change in climate. Balajee et al. (2007) also reported that for the increasing number of isolates that are uncommon, atypical, or unusual, DNA-based identification methods are being increasingly employed in many clinical laboratories.

According to Havlickova et al. (2008), dermatomycoses accounts for 20-25\% mycotic infection worldwide. An effective treatment and prevention of dermatomycoses depend on knowledge of the specific dermatophyte. This study therefore aims at isolating and identifying this group of human pathogenic fungi responsible for dermatomycoses using molecular methods.

\section{MATERIALS AND METHODS}

Samples collection: Stock cultures of sixteen different isolates of human pathogenic fungi were collected in
Mc-Cartney bottles from the Mycology unit of Department of Botany, University of Lagos. These were sub cultured on freshly prepared commercially produced Sabouraud dextrose agar (SDA). The Sabouraud dextrose agar (SDA) was prepared according to manufacturer specification (Oxoid, Basingstoke, England).

DNA extraction: Extraction of fungal DNA was done using 4 different protocols namely Cetyltrimethyl ammonium bromide (CTAB) protocol, Modified CTAB protocol, Zymo kit by Zymo Research Corp (Hatfield-Pretoria 0028, South Africa) and GNOME kit by Qbiogene Corp.

DNA extraction using CTAB protocol: Ten millilitres $(10 \mathrm{ml})$ of sterilized distilled water was added to fresh pure culture of each isolate to be extracted, a suspension was made by gently probing the colony with the tip of a sterilised Pasteur pipette. The suspension was transferred into an eppendorf tube, and was spin for 30 seconds. The supernatant was decanted and $400 \mu 1$ of CTAB buffer and $75 \mu 1$ of 10 $\%$ SDS were added to the pellet. This was then incubated in water bath at the temperature of $65{ }^{\circ} \mathrm{C}$ for fifteen minutes. Five hundred microlitres $(500 \mu \mathrm{l})$ of chloroform was added and this was mixed by rocking on an orbital shaker at $100 \mathrm{rpm}$ for 5 minutes, which was then spinned at $10,000 \mathrm{rpm}$ for 10 minutes. The supernatant was collected into fresh eppendorf tube and $500 \mu \mathrm{l}$ of iso-propanol was added to the supernatant. This was kept at $-20{ }^{\circ} \mathrm{C}$ for one hour after which it was spin at $14,000 \mathrm{rpm}$ for ten minutes. The supernatant was decanted gently and the pellet (DNA) was washed with $70 \%$ ethanol then, the pellet was air dried for thirty minutes. The dried 
pellet was then re-suspended in $200 \mu$ l of sterile distilled water.

DNA extraction using modified CTAB protocol: Ten millilitre $(10 \mathrm{ml})$ of isolation buffer (10X CTAB) containing $80 \mu \mathrm{l}$ of meta-mercaptoethanol in $50 \mathrm{ml}$ blue cap tubes was pre-heated in $65{ }^{\circ} \mathrm{C}$ water bath. One gramme $(1 \mathrm{~g})$ of freshly scrapped pure culture plates of each fungal isolates was added to the preheated isolation buffer in each tube. The mixture was then incubated at $65{ }^{0} \mathrm{C}$ for 15 minutes. Ten millitre $(10 \mathrm{ml})$ of SEVAG $(24: 1$ chloroform: Isoamyl achohol), then mixed gently but thoroughly. The cap of the tubes containing the mixture was then open to release gas, which was re-tightened then rocked the tubes using an orbital shaker $(100 \mathrm{rpm})$ for 60 minutes. After rocking, the tubes were spinned at $4000 \mathrm{rpm}$ at $25^{0} \mathrm{C}$ for 20 minutes. The mixture gave a clear and colourless aqueous solution at the top (containing the DNA), the clear colourless aqueous was removed into another set of tubes with the aid of a plastic transfer pipette. Two-third volume of isopropanol was added to the aqueous solution. The mixture was then mixed gently and stored in freezer $\left(-20^{\circ} \mathrm{C}\right)$ for 24 hours. This was to allow the DNA in it to precipitate. The mixture was later spinned in centrifuge at $3000 \mathrm{rpm}$ for 5 minutes to collect the precipitate, and the liquid in the tube was discarded. Then $3 \mathrm{ml}$ of $70 \%$ ethanol was added to dislodge the pellet in order to facilitate 'washing'. It was spinned again at $3000 \mathrm{rpm}$ for 5 minutes, the liquid was discarded and the alcohol was allowed to evaporate by leaving the tubes open and on its side. The DNA was re-suspended in $1.5 \mathrm{ml}$ of water and stored at $20^{\circ} \mathrm{C}$ prior shipments for PCR and Sequencing.

DNA extraction using GNOME kit: A fresh pure culture of each fungal isolates was scraped into a micro-centrifuge tube and suspended in $200 \mu \mathrm{l}$ extraction buffer (2\% Triton X-100, 1\% SDS, 100 $\mathrm{mM} \mathrm{NaCl}, \quad 10 \mathrm{mM}$ Tris-HCl, $\mathrm{pH} 8.0,1 \mathrm{mM}$ $\mathrm{Na}_{2}$ EDTA). The suspension was centrifuged for 5 $\mathrm{min}$ at $13,500 \mathrm{rpm}$. The supernatant was transferred to a new micro-centrifuge tube, and the nucleic acids were precipitated by adding $1 \mathrm{ml}$ absolute ethanol. Suspensions were mixed and centrifuged for $2 \mathrm{~min}$ (13,500 rpm). The pellet was re-suspended in $400 \mu \mathrm{l}$ Tris-EDTA, $\mathrm{pH} 8.0,3 \mu \mathrm{l}$ RNAse $(10 \mathrm{mg} / \mathrm{ml})$ and incubated for $5 \mathrm{~min}$ at $37^{\circ} \mathrm{C}$. Then, $10 \mu \mathrm{l}$ ammonium acetate $(4 \mathrm{M})$ and $1 \mathrm{ml}$ absolute ethanol were added and gently mixed. This mixture was centrifuged for 3 min at 13,500 rpm and the supernatant discarded. The DNA pellet was dried in airflow for $15 \mathrm{~min}$ and finally resuspended in $40 \mu \mathrm{l}$ sterile distilled water.

DNA extraction using ZYMO kit: Ten grammes of freshly prepared pure fungal culture plate of each isolate was scrapped and suspended in $50 \mu 1$ of water to the tubes of a ZR BashingBead ${ }^{\mathrm{TM}}$ Lysis Rack. Four hundred microlitres $(400 \mu \mathrm{l})$ of Lysis Solution was added to each tube. Tubes cap were tight to prevent leakage. The ZR BashingBead ${ }^{\mathrm{TM}}$ Lysis Rack was Centrifuge at 5,500 rpm for 5 minutes. Two hundred and fifty microlitres $(250 \mu \mathrm{l})$ of the supernatant was transferred to each well of a Deep-Well Block. Seven hundred and fifty microlitres $(750 \mu \mathrm{l})$ of Fungal DNA Binding Buffer was added to the supernatant in the Deep-Well Block from Step 3. Completely covered with cover foil then mixed thoroughly by vortexing block for 2 minutes. The Deep-Well Block was centrifuge at 5,000 rpm for 5 minutes. After removing cover foil, $500 \mu \mathrm{l}$ of each of the supernatants from Step 5 was transferred to the wells of Silicon-A ${ }^{\mathrm{TM}}$ Plate on a collection plate. The assembly was centrifuge at 5,000 rmp for 5 minutes. The flow was discarding through from the collection plate and repeat Step 5. Two hundred microlitres $(200 \mu \mathrm{l})$ of DNA Pre-Wash Buffer was added to the wells of the Silicon-A ${ }^{\mathrm{TM}}$ Plate on the emptied Collection Plate and centrifuge the assembly at $5,000 \mathrm{rpm}$ for 5 minutes. Five hundred microlitres $500 \mu \mathrm{l}$ Fungal DNA Wash Buffer was added to the wells of the Silicon-A ${ }^{\mathrm{TM}}$ Plate on the collection plate and centrifuge the assembly at $5,000 \mathrm{rpm}$ for 5 minutes. The Silicon- $\mathrm{A}^{\mathrm{TM}}$ Plate was transferred to an Elution Plate and $100 \mu \mathrm{l}$ DNA Elution Buffer was added directly to the matrices in the plate. The assembly was centrifuged at $5,000 \mathrm{rpm}$ for 5 minutes.

DNA verification on $1 \%$ agarose gel electrophoresis: One percent $(1 \%)$ of agarose gel was prepared by mixing $1.5 \mathrm{~g}$ agarose with $150 \mathrm{ml} 1 \mathrm{X}$ TBE Buffer. The mixture was boiled in a microwave until all agarose has dissolved (usually, two minutes). This was cooled down under running cold tap water; after which, $6 \mu 1$ of Ethidium Bromide was added and swirled to mix (done in the fume-hood). The gel was then poured into the tray and allowed to stand for at least thirty minutes before removing the combs. The gel was then placed in an electrophoresis tank. Five microliters of loading dye was spotted for $10 \mu \mathrm{l}$ of each DNA sample on a parafilm paper. Using a pipette, $15 \mu 1$ of each sample was loaded into each "well" of the prepared $1 \%$ agarose gel; also one-half microgram of $1 \mathrm{~kb}$ ladder (Lambda DNA Hindlll) was loaded into the "marker" well. It was run for 45minutes at $110 \mathrm{Milli}$ Amps. The set-up was then viewed under the ultraviolet trans-illuminator for DNA quality and yield assessments and the photograph was taken.

Polymerase Chain Reaction (PCR) and DNA sequence: The Polymerase Chain ReactionRestriction Fragment Length Polymorphism (PCRRFLP) is used to amplify the internal transcribed spacer (ITS) region of the rDNA. The PCR was performed using the universal primer pair ITS1-ITS4 (Jackson et al., 1999). The thermal cycler was 
programmed for $4 \mathrm{~min}$ at $948 \mathrm{C}$ followed by 35 cycles of $1 \mathrm{~min}$ at $948 \mathrm{C}, 2 \mathrm{~min}$ at $588 \mathrm{C}$ and $1.5 \mathrm{~min}$ at $728 \mathrm{C}$. The nucleotide sequences were determined automatically using the cycle sequencing protocol by the BigDye Terminator v3.1 Cycle Sequencing Kit in the ABI PRISM 377-DNA Sequencer. Further identification and blasting in order to confirm their identification was achieved by comparing nucleotide sequences data that was produced from the fungal DNA extracted to sequences database at the genbank and calculated the statistical significance of matches. BLAST (Basic Local Alignment Search Tool), is a program used to infer functional and evolutionary relationships between sequences as well as to help identify members of gene families.

\section{RESULTS AND DISCUSSION}

The extracted genomic DNA from each of the isolated fungus which was size separated on $1 \%$ Agarose gel are as shown in Plates 1a-d. Plate 1a shows the electrophorogram of fungal DNA extracted with the CTAB protocol, this protocol extracted DNA of all the fungal isolates and showed good bands on the electrophorogram expect for the dermatophytes isolates (first lane: well 4, 5, 6, \& 7) (Table 1). Plate $1 \mathrm{~b}$ shows the electrophorogram of fungal DNA extracted with the modified CTAB protocol. Here, it was also noted that this protocol was only able to extract few fungal while dermatophytes isolates were among those not extract. Same results was noted with extraction done with the GNOME kit (Plate 1c) where only the dermatophytes species DNA (first lane, well 2 and 3) did not show any band on the electrophorogram. This is not the same with extraction results done with the Zymo kit as shown in Plate 1d. Here, the entire extracted fungal DNA showed good band on the electrophorogram.

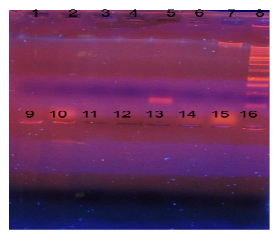

Plate 1a: Electrophorogram of extracted DNA samples using the $\mathrm{CTAB}$ protocol. The first lane contains the marker, $\mathrm{C} 7, \mathrm{C} 8, \mathrm{~B} 3$, B4, B5, B6, D9. The second lane contains marker, D11, D12, D13, D14, D15, D16 and D10.

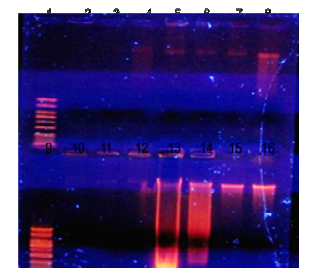

Plate 1b: Electrophorogram of extracted DNA samples using the modified CTAB protocol. The first lane contains B1, B2, B3, B4, C8, C7, D9 and the marker. The second lane contains D10, D11, D12, B5, B6, D14, D16 and D13.
The sub culture of the fungal isolates revealed that six of the isolates are likely to be dermatophytes due to their slow growing nature. These isolates showed colonies on the SDA plates after day 12 of sub culturing (Table 1). Other fungal isolates showed growth colonies within 48 hours of incubation.

The genera Microsporum, Trichophyton and Epidermaphyton were the group of dermatophytes identified (Table 3). These included: Epidermophyton floccosum, Microsporum audouinii, Microsporum nanum, Trichophyton concentricum Trichophyton mentagrophytes var. quinckeanun, and Trichophyton violaceum. On the basis of their primary habitat associations, the above isolates are of three groups. These are the anthropophilic, zoophilic, and geophilic as depicted in Table 2. Two of the other identified species of the isolated fungi belong to the systemic mycoses group otherwise known as the "deep mycoses" and these are Blastomyces dermatitidis and Exophiala dermatitidis The other eight species of the isolated fungi belong to the opportunistic mycoses group, and these include: Absidia corymbifera, Aspergillus terreus, Emericlla nidulans, Mucor racemosus, Pencillium aschersonia, Pencillium citrinum, Aspergillus flavus, Aspergillus fumigatus.

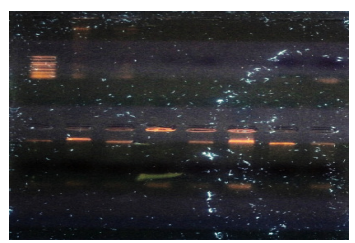

Plate 1c: Electrophorogram of extracted DNA samples using the Gnome kits. The first lane contains the marker, B3, B4, C7, C8, D9, D10, D11. The second lane contains the marker, C8, D9, D12, D13, D14, D15 and D16.

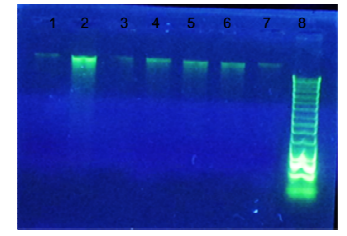

Plate 1d Electrophorogram of extracted DNA samples using the Zymo kits. The lanes labelled 1,2,3,4,5,6,7,8 contained sample number B1, B3, C7, B2, B4, B5, B6 and the Marker respectively.

The isolation and adequate identification of human pathogenic fungi is significant to clinical diagnosis and appropriate treatment of fungal infection in medical mycology. Over the years, it is noted that fungal isolates have been identified based on observations of colonial and microscopic morphology, along with tables, keys and textbook descriptions. Although, according to Balajee et al. (2007) this approach still has value for the identification of many fungal organisms, but requires expertise and can be problematic in determining a 
species identification that is timely and useful in the management of high-risk patients.

Using four distinct DNA extraction protocols, six species from the three genera of dermatophytes, two species of systemic mycoses and eight species of opportunistic mycoses fungi were isolated and identified. According to Fredricks et al., (2005) no single extraction method amongst those currently available is optimal for the molecular analysis of fungi. From the result of this present study, no single protocol was able to isolate all DNA from the samples. This agrees with the work of Knudsen et al. (2016) who had to use eight commonly used DNA extraction kits and sixteen protocols to extract quality DNA from human faeces, pig faeces and hospital sewages. They further concluded that DNA concentration, purity, and stability depend on the type of specimen and DNA isolation method. The quality of DNA extracted from the samples varied with the type of extraction protocol used. Of the four protocols used in the present study, quality DNA for molecular analysis was only extracted using Zymo kit. This could have been due to the ability to lyse the fungal cell wall. Zhang et al. (1996) and Muller et al. (1998) remarked that the major challenge for isolation of DNA of good quality and quantity from fungi lies in breaking the rigid cell walls, due to fungal nucleases and high polysaccharide contents of the cell wall. Melo et al., (2006) agreed with Zhang et al., (1996) and Muller et al. (1998) by concluding that DNA isolation from some fungal species is difficult. This is because they have cell walls or capsules that are relatively unsusceptible to lysis. Although dermatophyte infections are treatable, there is a high rate of reinfection as a result of poor analysis of the causal organism. Of the four DNA extraction protocols employed in the study, the CTAB protocol, Modified CTAB protocol and the GNOME kit were able to extract DNA from the non-dermatophytic group. Only the Zymo DNA kit was able to extract DNA from the dermatophytic group. Growth of the non-dermatophytes group was noted in the fourth day of incubation which could lead to ineffective diagnoses if the observation was to stop there because the dermatophytic group started growing between day 12 - 14 of incubation. The result from this present study is in agreement with previous works (Fredricks et al., 2005; Leite et al., 2014) as it shows that no single DNA extraction protocol can isolate fungal DNA from the three groups of fungi encountered.

Conclusion: The results from this study revealed that DNA extraction which is the first step in all molecular studies showed that one DNA extraction method might not be able to extract all fungal DNA. The purity and yield of different fungal DNA extracts leads to adequate and effective sequence data for accurate identification, proper diagnosis and better understanding of the etiology of this group of pathogenic fungi in the prevention, treatment and eradication of infectious diseases.

Table 1: Fungal isolates showing

\begin{tabular}{|c|c|c|c|c|}
\hline $\mathbf{S} / \mathbf{N}$ & Fungi & Code & $\begin{array}{l}\text { Day growth } \\
\text { was observed }\end{array}$ & $\begin{array}{l}\text { Growth } \\
\text { rate } \\
(\mathrm{mm})\end{array}$ \\
\hline $\mathbf{1}$ & Microsporum nanum & B1 & 14 & 5.0 \\
\hline 2 & Microsporum audouiii & $\mathrm{B} 2$ & 14 & 5.0 \\
\hline 3 & Trichophyton concentricum & B3 & 14 & 5.0 \\
\hline 4 & Epidermaphton fluccosum & B4 & 13 & 5.0 \\
\hline 5 & Trichophyton mentagrophytes & B5 & 14 & 5.0 \\
\hline 6 & Trichophyton violaceum & B6 & 15 & 5.0 \\
\hline 7 & Exophiala dermatitidis & $\mathrm{C} 7$ & 6 & 5.0 \\
\hline 8 & Blastomyces dermatitidis & $\mathrm{C} 8$ & 6 & 5.0 \\
\hline 9 & Emericella nudulans & D9 & 4 & 5.0 \\
\hline 10 & Aspergillus terreus & D10 & 4 & 5.0 \\
\hline 11 & Absidia corymbifera & D11 & 4 & 5.0 \\
\hline 12 & Penicillium aschersonia & D12 & 4 & 5.0 \\
\hline 13 & Penicillium citrinum & D13 & 4 & 5.0 \\
\hline 14 & Mucor racemosus & D14 & 4 & 5.0 \\
\hline 15 & Aspergillus flavus & D15 & 4 & 5.0 \\
\hline 16 & Aspergillus fumigatus & D16 & 4 & 5.0 \\
\hline
\end{tabular}

Table 2: The three groups of isolated dermatophytes based on their primary habitat

\begin{tabular}{|c|c|c|c|c|}
\hline Primary habitat & & Isolates & & \\
\hline Anthropophilic & Epidermophyton floccosum & Microsporum audouinii & $\begin{array}{l}\text { Trichophyton } \\
\text { violaceum }\end{array}$ & $\begin{array}{c}\text { Trichophyton } \\
\text { concentrium }\end{array}$ \\
\hline Zoophilic & $\begin{array}{l}\text { Trichophyton mentagrophytes var. } \\
\text { quinckeanum }\end{array}$ & & & \\
\hline Geophilic & Microsporum nanum & & & \\
\hline
\end{tabular}


Table 3: Generated sequence data from the isolated fungi and the percentage of their significance of matches with the sequences database at the Genbank

\begin{tabular}{|c|c|}
\hline Sequence data & Organism and \% of significant match \\
\hline 110719-03_A07_TOC -ITS1 & This sequences data was $99 \%$ significant matched with \\
\hline AACATGCGTGAGATTGTAAGTCTAGCTTTCCCCCTGTCC & Trichophyton mentagrophytes var. quinckeanum \\
\hline \multicolumn{2}{|l|}{$\begin{array}{l}\text { ATCACTTCCCCTCTATTTGGATAATGTTGCCCACTTAAG } \\
\text { CGTCCGCTTCA }\end{array}$} \\
\hline 110719-09_I05_TOD-ITS4 & This sequences data was $99 \%$ significant matched with \\
\hline GGACGAGGGCCCAACACACAAGCCGGGCTTGAGGGCA & Aspergillus terreus \\
\hline \multicolumn{2}{|l|}{ GCAATGACGCTCGGACAGGCATGCCCCCCGGAATACCA } \\
\hline \multicolumn{2}{|l|}{ GGGGGCG } \\
\hline 110719-03_K05_TOE-ITS1 & This sequences data was $99 \%$ significant matched with \\
\hline TGGCCACTTGAACACAACTTGTTGGACCACGCTTACAT & Blastomyces dermatitidis \\
\hline \multicolumn{2}{|l|}{$\begin{array}{l}\text { GCATGTGGGTTCATTTTTCGAACCGACGCCGCCTTCTA } \\
\text { ACTC }\end{array}$} \\
\hline 110719-03_E07_TOG-ITS4 & This sequences data was $97 \%$ significant matched with \\
\hline CACTGAACTTCATGCCTGAGAGTGATGCAGTCTGAGCC & Exophiala dermatitidis \\
\hline \multicolumn{2}{|l|}{ TGAATACAAATCAGTCAAAACTTTCAACAATGGATCTCT } \\
\hline \multicolumn{2}{|l|}{ TGGTTCCGGCA } \\
\hline 110719-09_A07_TOH-ITS & This sequences data was $98 \%$ significant matched with \\
\hline CGGCTGGCGCCCGGCCGGCCCTAATCGAGCGGGTGAC & Microsporum audouinii \\
\hline \multicolumn{2}{|l|}{ AAAGCCCCATACGCTCGAGGACCGGACACGGTGCCGCC } \\
\hline \multicolumn{2}{|l|}{ GCTGCCTTTC } \\
\hline 110719-03_G07_TOI-ITS1 & This sequences data was $97 \%$ significant matched with \\
\hline ACCACTGAACTTCATGCCTGAGAGTGATGCAGTCTGAG & Penicillium citrinum \\
\hline \multicolumn{2}{|l|}{ CCTGAATACAAATCAGTCAAAACTTTCAACAATGGATCT } \\
\hline \multicolumn{2}{|l|}{ CTTGGTTC } \\
\hline 110719-03_M07_TOM-ITS1 & This sequences data was $99 \%$ significant matched with \\
\hline CTCCGTCAGGCTTTCTTCTCCAGTTTTTGACAGGGATTT & Penicillium aschersonia \\
\hline \multirow{2}{*}{\multicolumn{2}{|c|}{$\begin{array}{l}\text { CTTGTCGTTATACCTATTTCCCTACAATTACCTCCTGCC } \\
\text { TTCGATTGCTGG }\end{array}$}} \\
\hline & \\
\hline 110719-09_K07_TOP-ITS4 & This sequences data was $99 \%$ significant matched with \\
\hline GGCCCTAGTCGAGCGGGTGACAAAGCCCCATACGCTCG & Epidermaphyton fluccosum \\
\hline \multicolumn{2}{|l|}{ AGGACCGGACACGGTGCCGCCGCTGCCTTTCGGGCCCG } \\
\hline 110719-03_A09_TOQ-ITS1 & \\
\hline ACTTCATGCCTGAGAGTGATGCAGGCTGGCTCTGAATC & Mucor racemosus \\
\hline \multicolumn{2}{|l|}{ TAAAGCAAAACTTTCTTCCTGAATCTTTTGCTTCCCGCC } \\
\hline \multicolumn{2}{|l|}{ TCCA } \\
\hline 110719-03_C09_TOR-ITS1 & This sequences data was $95 \%$ significant matched with \\
\hline AACATGCGTGAGATTGTAAGTCTAGCTTTCCCCCTGTCC & Trichophyton concentricum \\
\hline \multicolumn{2}{|l|}{ ATCACTTCCCCTCTATTTGTGGTAGATTGCGACGTGCG } \\
\hline 110719-09_O07_TOS-ITS4 & This sequences data was $96 \%$ significant matched with \\
\hline 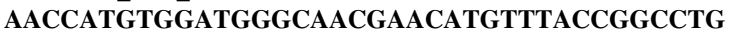 & Absidia corymbifera \\
\hline \multicolumn{2}{|l|}{$\begin{array}{l}\text { ATAATTTTGCTTAAGCCTGGTATCCTATTAAAACTCTAC } \\
\text { CTTCAGAT }\end{array}$} \\
\hline 110719-09_K05_TOU-ITS4 & This sequences data was $98 \%$ significant matched with \\
\hline ATGCGTCGGCGGGCGCCGGCCGGGCCTACGGAGCGGA & Microsporum nanum \\
\hline \multirow{2}{*}{\multicolumn{2}{|c|}{$\begin{array}{l}\text { AGACGAAGCCCCATACGCTCGAGGACCGGACGCGGTG } \\
\text { CCGCCGC }\end{array}$}} \\
\hline & \\
\hline 110719-09_I05_TOW-ITS4 & This sequences data was $99 \%$ significant matched with \\
\hline AACATGCGTGAGATTGTAAGTCTAGCTTTCCCCCTGTCC & Trichophyton violaceum \\
\hline ATCACTTCCCCTCTATTTGCCCCCGGGAGCCGGGGGAC & \\
\hline GAGGGCCCA & \\
\hline 110719-03_E05_TOY-ITS1 & This sequences data was $99 \%$ significant matched with \\
\hline ACGGATCTCTTGGTTCCGGCATCGATGAAGAACGCAGC & Emericella nidulans \\
\hline GAAATGCGATAACTAATGTGAATTGCAGAATTCAGTGA & \\
\hline ATCATCG & \\
\hline 110719-09_I05_TOB-ITS4 & \\
\hline AAACAGTTGGGCATGAAATGCACTCTAAACCTTACACA & This sequences data was $97 \%$ significant matched with \\
\hline CAGTGTCTATACAACTCTTGCTGGTTTGGCCTAGGGTA & Aspergillus flavus \\
\hline GGTTG & \\
\hline 110719-03_E05_TOV-ITS1 & \\
\hline АСАААТТААТАТСТСАТGАТААТСТТСААААСТСААСАА & \\
\hline $\begin{array}{l}\text { CGGATCTCTTGGTTCTCTATCGATGAAAACCACGAAAT } \\
\text { GATAAGTAATA }\end{array}$ & $\begin{array}{l}\text { This sequences data was } 97 \% \text { significant matched with } \\
\text { Aspergillus fumigatus }\end{array}$ \\
\hline
\end{tabular}

Acknowledgements: The authors thank the Mycology unit, Department of Botany, University of Lagos for the provision of the fungal isolates. 


\section{REFERENCES}

Adetosoye, AI (1977). Dermatophytosis survey in Lagos State of Nigeria. Trans. R. Soc. Trop. Med. Hyg. Discipline 71(4): 322 - 324.

Anosike, JC; Keke, IR; Uwaezuoke, JC; Anozie, JC; Obiukwu, C.E; Nwoke, BEB; Amajuoyi, O.U. (2005). Prevalence and distribution of ringworm infection in primary school children in parts of Eastern, Nigeria. J Appl Sci Environ Manag. 9(3): 21 - 25.

Balajee, SA; Sigler, L; Brandt, ME (2007). DNA and the classical way: Identification of medically important molds in the 21 st century. Med Mycology 45: 475-490

Fredricks, DN; Smith, C; Meier, A (2005). Comparison of six DNA extraction methods for recovery of fungal DNA as assessed by quantitative PCR. J. Clin. Microbiol., 43: 5122 5128.

Havlickova, B; Czaika, VA; Friedrich, M (2008). Epidemiological trends in skin mycoses worldwide. Mycoses 51: 2-15.

Lakshmanan, A; Ganeshkumar, P; Mohan, SR; Hemamalini, M; Madhavan, R (2015). Epidemiological and clinical pattern of dermatomycoses in rural India. Indian J. Med. Microbiol., 33:(1): 134-136.

Leite, DCA; Balieiro, FC; Pires, CA; Madari, BE; Rosado, AS; Coutinho, HLC; Peixoto, RS (2014). Comparison of DNA extraction protocols for microbial communities from soil treated with biochar. Braz J Microbiol., 45(1): 175-183
Melo, SCO; Pungartnik, C; Cascardo, JCM; Brendel, M (2006). Rapid and efficient protocol for DNA extraction and molecular identification of the basidiomycete Crinipellis perniciosa. Genet. Mol. Res. 5(4): 851-855.

Muller, FM; Werner, KE; Kasai, M; Francesconi, A; Chanock, SJ; Walsh, TJ (1998). Rapid extraction of genomic DNA from medically important yeasts and filamentous fungi by high-speed cell disruption. J. Clin. Microbiol. 36: 1625-1629.

Ogbonna, CIC.; Robinson, RO; Abubakar, JM (1985). The distribution of ringworm infections among primary school children in Jos Plateau State of Nigeria. Mycopathologia 89: 101 - 106.

Teklebirhan, G; Bitew, A (2015). Prevalence of Dermatophytic Infection and the Spectrum of Dermatophytes in Patients Attending a Tertiary Hospital in Addis Ababa, Ethiopia. Int J Food Microbiol. 2015: doi: $10.1155 / 2015 / 653419$

Zhang, D, Yang, Y; Castlebury, L.A; Cerniglia, CE (1996). A method for the large scale isolation of high transformation efficiency fungal genomic DNA. FEMS Microbiology Letters 145(2): 261265. 